\title{
ANALISIS KESALAHAN BERBAHASA PADA SOSIAL MEDIA INSTAGRAM DALAM POSTINGAN, KOMENTAR, DAN CERITA SINGKAT
}

\author{
Sri Kurnia Hastuti Sebayang, Anita Soleha Sofyan \\ STKIP Budidaya Binjai \\ Email : hastutisrikurnia@gmail.com
}

\begin{abstract}
ABSTRAK
Penelitian ini bertujun untuk memaparkan bentuk-bentuk kesalahan berbahasa yang terdapat pada media sosial instagram. Objek kajian dalam penelitian ini yaitu wacana status dan komentar teman di instragram, cerita dan komentar teman di instagram, dan percakapan di istragram. Data dalam penelitian ini yaitu berupa kata dan kalimat dalam status dan koment teman di instragram dan lain sebagainya, Sumber data berupa sumber data tertulis, yaitu status dan koment teman di instragram. Teknik pengumpulan data dalam penelitian ini menggunakan metode baca dan catat karena berupa tulisan. Metode baca adalah suatu pemerolehan data yang dilakukan dengan cara membaca suatu penggunaan bahasa. Baca dan catat merupakan proses yang didokumentasikan dengan cara mencatat data yang sudah terkumpul. Dari hasil penelitian ini dapat kita lihat bahwa bahasa yang kita gunakan di Instagram dan sosial media lainnya seiring dengan berjalannya waktu dapat menurunkan kaidah-kaidah yang terdapat didalamnya. Ini karena, sosial media merupakan tempat berkumpulnya semua ragam bahasa, baik yang masih dalam bahasa Indonesia maupun yang dari luar, yang mengakibatkan pengguna tidak lagi memperhatikan bagaimana menulis bahasa Indonesia yang benar.
\end{abstract}

Kata Kunci : kesalahan berbahasa, sosial media, instagram

\section{PENDAHULUAN}

Bahasa memiliki peran yang sangat penting. Bahasa menjadi alat yang paling efektif dalam setiap aktivitas komunikasi. Setiap manusia memerlukan bahasa agar dapat menyampaikan apa yang ada dalam pikirannya. Dalam pemakaiannya, bahasa menjadi sangat beragam. Keragaman bahasa sangat bergantung pada kebutuhan dan tujuan komunikasi. Bahasa dapat dilakukan secara lisan maupun tulisan. Seiring majunya peradaban manusia, termasuk di Indonesia, banyak cara yang dipilih pemakai bahasa dalam berkomunikasi. Bahkan pilihan cara komunikasi tidak hanya semakin beragam tapi juga semakin canggih. Sehingga menimbulkan kesalahan dalam penggunaan Bahasa Indonesia di era sekarang.

Di saat ini perkembangan semakin pesat. Perkembangan dan berbagai pengaruhpengaruh globalisasi semakin menjalar. Terutama di kalangan remaja. Di zaman sekarang serasa segalanya sudah berbeda, apalagi jika dibandingkan dengan zaman 


\section{Jurnal Serunai Bahasa Indonesia \\ Vol.16, No.1, Februari 2019 \\ e-ISSN 2621-5616}

dahulu. Dari segi tingkah laku dan gaya bahasa yang digunakan pun saat ini juga berbeda dengan dengan zaman dulu.

Salah satu fenomena komunikasi yang paling pesat saat ini adalah penggunaan bahasa yang didukung oleh perangkat teknologi canggih, khususnya bahasa yang digunakan pada jejaring sosial seperti Instagram, Namun penggunaan bahasa yang menyimpang dari kaidah Bahasa Indonesia menimbulkan sorotan besar dari para pengamat dan menjadi kesalahan dalam Berbahasa Indonesia. Bahkan kesalahan Berbahasa Indonesia memliki variasi mulai dari kesalahan ejaan, mencampurkan Bahasa Asing ke Indonesia, penggunaan tanda baca yang tidak tepat, dan lain sebagainya.

Pada awalnya, sosial media digunakan untuk menyampaikan informasi antar teman, dan menjadi ajang promosi. Bukan sebagai media mencari eksistensi. Parahnya lagi, banyak remaja yang membuat bahasa "gaul" itu pada jejaring sosial, bahkan remaja zaman sekarang curhat melalui Sosial Media dengan bahasa gaul, tanpa mempedulikan efek yang ditimbulkannya. Ini disebabkan karena mereka ingin menjadi trendsetter, mereka akan sangat bangga bila kata-kata mereka dapat simpati dari teman maya-nya, atau ditiru untuk mereka jadikan postingan, komentar dan cerita singkat Bahasa berdasarkan ruang lingkup berfungsi sebagai bahasa nasional dan bahasa kelompok. Melihat bahasa nasional di Indonesia adalah bahasa Indonesia, munculnya bahasa yang digunakan dalam jejaring sosial ini jelas merusak bahasa nasional.

\section{Kesalahan Berbahasa Indonesia}

Kesalahan berbahasa adalah pemakaian bentuk-bentuk tuturan berbagai unit kebahasaan yang meliputi kata, kalimat, paragraf, yang menyimpang dari sistem kaidah bahasa Indonesia baku, serta pemakaian ejaan dan tanda baca yang menyimpang dari sistem ejaan dan tanda baca yang telah ditetapkan sebagaimana dinyatakan dalam buku Ejaan Bahasa Indonesia yang Disempurnakan.

S. Piet Corder dalam bukunya Introducing Applied Linguistik menjelaskan bahwa kesalahan berbahasa adalah pelanggaran terhadap kode bahasa. Pelanggaran ini disebabkan kurang sempurnanya penguasaan dan pengetahuan terhadap kode. Kesalahan berbahasa tidak hanya dibuat oleh siswa yang mempelajari B2 (bahasa yang dipelajari siswa), tetapi juga dibuat siswa yang belajar B1 (bahasa ibu). Sedangkan 


\section{Jurnal Serunai Bahasa Indonesia \\ Vol.16, No.1, Februari 2019 \\ e-ISSN 2621-5616}

analisis kesalahan berbahasa adalah suatu cara atau langkah kerja yang biasa digunakan oleh peneliti atau guru bahasa untuk mengumpulkan data, mengidentifikasi kesalahan, menjelaskan kesalahan, mengklasifikasikan kesalahan dan mengevaluasi taraf keseriusan kesalahan berbahasa.

Kesalahan berbahasa biasanya ditentukan berdasarkan ukuran keberterimaan. Apakah bahasa (ujaran atau tulisan) si pembelajar bahasa itu berterima atau tidak bagi penutur asli atau pengajarnya. Jadi, jika pembelajar bahasa Indonesia membuat kesalahan, maka ukuran yang digunakan adalah apakah kata atau kalimat yang digunakan pembelajar benar atau salah menurut penutur asli bahasa Indonesia. Jika kata atau kalimat yang digunakan pembelajar bahasa tadi salah, dikatakan pembelajar bahasa membuat kesalahan. Ukuran berbahasa yang baik ini adalah ukuran intrabahasa atau intralingual. Ukuran kesalahan dan ketidaksalahan intrabahasa adalah ukuran kebahasaan. Ukuran kebahasaan meliputi :

1. Fonologi (tata susun) Ilmu tentang bunyi-bunyi (fonem) bahasa dandistribusinta. Fonolgi diartikan sebagai kajian bahasa yang mempelajari tentang bunyi-bunyi bahasa yang diproduksi oleh alat ucap manusia.

2. Morfologi (tata kata) Ilmu bentuk kata adalah cabang linguistik yang mengidentifikasi satuan-satuan dasar bahasa sebagai satuan gramatikal. Morfologi mempelajari seluk-beluk bentuk kata serta pengaruh perubahan-perubahan bentuk kata terhadap golongan dan arti kata.

3. Sintaksis (tata kalimat) Cabang tata bahasa mengenai studi penghimpunan kata-kata dalam kalimat-kalimat dan alat dengan mana hubungan seperti itu terlihat.

4. Semantik (tata makna)Studi tentang makna yang digunakan untuk memahami ekspresi manusia melalui bahasa.

Seorang pakar linguistik Noam Comsky membedakan antara kesalahan berbahasa(error) dengan kekeliruan berbahasa(mistake), keduanya memang sama-sama pemakaian bentuk tuturan yang menyimpang, akan tetapi kesalahan berbahasa terjadi secara sistematis karena belum dikuasainya kaidah bahasa yang benar. Sedangkan kekeliruan berbahasa bukan terjadi secara sistematis, melainkan dikarenakan gagalnya merealisasikan kaidah bahasa yang sebenarnya sudah dikuasai. 


\section{Jurnal Serunai Bahasa Indonesia \\ Vol.16, No.1, Februari 2019 \\ e-ISSN 2621-5616}

Kekeliruan dalam berbahasa disebabkan karena faktor performansi, sedangkan kesalahan berbahasa disebabkan faktor kompetensi. Faktor performansi meliputi keterbatasan ingatan atau kelupaan sehingga menyebabkan kekeliruan dalm melafalkan bunyi bahasa, kata, urutan kata, tekanan kata atau kalimat. Kekeliruan ini bersifat acak, maksudnya dapat terjadi pada berbagai tataran linguistik. Kekeliruan biasanya dapat diperbaiki sendiri yang bersangkutan dengan cara lebih mawas diri dan lebih memusatkan perhatian. Sedangkan kesalahan yang di sebabkan faktor kompetensi adalah kesalahan yang disebabkan seseorang belum memahami sistem linguistik bahasa yang digunakannya. Kesalahan berbahasa akan sering terjadi apabila pemahaman mahasiswa/i tentang sistem bahasa kurang. Kesalahan berbahasa dapat berlansung lama apabila tidak diperbaiki. Dosen dapat melakukan perbaikan dengan melalui revisi, latihan, praktik, dan lain sebagainya.

\section{Faktor Remaja Zaman sekarang menggunakan sosial media}

1. Faktor Pergaulan, pergaulan remaja saat ini bisa dikatakan luas karena banyaknya sosial media dunia maya yang menghubungkan mereka satu sama lain. Instagram misalnya, pada media inilah muncul dan berkembang bahasa Alay yang dituliskan pada status yang kemudian akan dibaca oleh remaja lain dan akan mengikuti pemakaian bahasa Alay sehingga semakin marak digunakan oleh para remaja. Bahasa ini berkembang di kalangan remaja, namun dalam pergaulan media jejaring sosial paling sering digunakan. Semakin lama bahasa ini kian berkembang sehingga telah dianggap wajar pada kalangannya. Dalam bahasa Alay, remaja bebas menyingkat bahasa sesuai dengan keinginan mereka.

2. Faktor Gengsi, Banyak remaja yang berusaha ingin menjadi anak gaul yang tidak ketinggalan jaman, hal ini menuntut mereka mengikuti perkembangan jaman salah satunya mengggunakan bahasa Alay di sosial media, akronim dari anak lebay, yakni bahasa tulis berupa campuran bahasa gaul lisan, bahasa asing khususnya Inggris, singkatan, kode, angka, dan simbol. Alasan menggunakan bahasa ini karena tidak ingin disebut anak kampungan.

3. Faktor Iklan Kegemaran sesorang menonton sinetron, film bahkan iklan, sedikit mempengaruhi dalam pemakaian bahasa sehari-hari. Bahasa yang digunakan oleh para remaja dikarenakan oleh apa yang mereka dengarkan. Pada telivisi misalnya, 


\section{Jurnal Serunai Bahasa Indonesia \\ Vol.16, No.1, Februari 2019 \\ e-ISSN 2621-5616}

banyak sinetron, film bahkan iklan yang telah menggunakan dan ikut membantu mempopularkan bahasaAlay tersebut. Sehingga para remaja yang melihat akan mengikuti dan menggunakan bahasa Alay pada keseharian mereka sesama pengguna bahasa Alay agar dianggap gaul dan keren seperti para artis dan bintang iklan yang menggunakan bahasa Alay tersebut. Tanpa menyadari bahwa bahasa yang digunakan oleh publik figur itu hanya tuntutan skenario.

\section{Tataran Morfologi}

Morfologi merupakan suatu cabang linguistik yang mempelajari tentang susunan kata atau pembentukan kata. Menurut Ralibi, secara etimologis istilah morfologi berasal dari bahasa Yunani, yaitu berasal dari gabungan kata morphe yang berarti 'bentuk', dan logos yang artinya 'ilmu'. Chaer berpendapat bahwa morfologi merupakan ilmu mengenai bentuk-bentuk dan pembentukannya.

\section{METODE}

Penelitian ini menggunakan metode kualitatif yang bersifat deskriptif. Metode kualitatif adalah penelitian yang bermaksud untuk memahami fenomena tentang apa yang dialami oleh subjek penelitian (Moleong, 2004: 6). Penelitian ini bersifat deskriptif karena lebih mementingkan proses dari pada hasil. Objek kajian dalam penelitian ini yaitu wacana status dan komentar teman di Facebook, cerita dan komentar teman di instagram, dan percakapan grup di whatsapp. Data dalam penelitian ini yaitu berupa kata dan kalimat dalam status dan koment teman di Istagram. Sumber data berupa sumber data tertulis, yaitu status dan coment teman di Instagram dan lain sebagainya.

Teknik pengumpulan data dalam penelitian ini menggunakan metode simak dan catat karena berupa tulisan. Metode simak adalah suatu pemerolehan data yang dilakukan dengan cara menyimak suatu penggunaan bahasa (Mahsun, 2005: 90). Simak dan catat merupakan proses yang didokumentasikan dengan cara mencatat data yang sudah terkumpul. 


\section{Jurnal Serunai Bahasa Indonesia \\ Vol.16, No.1, Februari 2019 \\ e-ISSN 2621-5616}

\section{HASIL DAN PEMBAHASAN}

\section{Wujud Kesalahan Penggunaan Bahasa Indonesia di Instagram}

Kesalahan ejaan termasuk dalam bidang kesalahan bahasa. Penelitian ini akan mengkaji tentang kesalahan-kesalahan ejaan yang ditemukan pada status dan komentar facebook, status dan cerita di instagram, ceritan dan percakapan grup di whatsaap. Kesalahan ejaan meliputi kesalahan pemakaian huruf kapital dan kesalahan penggunaan tulisan.

Tabel 1: kesalahan Ejaan

\begin{tabular}{|c|c|c|c|}
\hline $\begin{array}{l}\text { Nomor } \\
\text { data }\end{array}$ & $\begin{array}{l}\text { Jenis kesalahan } \\
\text { penulisan }\end{array}$ & Kalimat & Keterangan \\
\hline Data 1 & $\begin{array}{l}\text { Cerita singkat } \\
\text { @ syahirahsalsabil } \\
\text { Kuy, adek, ga }\end{array}$ & $\begin{array}{l}\text { Hai.. kuy yang } \\
\text { punya adek ikutan } \\
\text { lomba ya kali ga } \\
\text { ikut }\end{array}$ & $\begin{array}{l}\text { Kata kuy, adek, dan ga adalah } \\
\text { bahasa gaul zaman sekarang, } \\
\text { Penulisan yang sesuai } \\
\text { dengan ejaan adalah ayo, adik, dan } \\
\text { tidak }\end{array}$ \\
\hline Data 2 & $\begin{array}{l}\text { Komentar } \\
\text { @ tania_rozika12 } \\
\text { sedap, d, tengok }\end{array}$ & Sedap d tengok kan & $\begin{array}{l}\text { Kata sedap, d, dan tengok, } \\
\text { termasuk bahasa yang disingkat- } \\
\text { singkat, penulisan yang sesuai } \\
\text { dengan ejaan adalah enak, di, lihat. }\end{array}$ \\
\hline Data 3 & $\begin{array}{l}\text { Postingan @ Tiara } \\
\text { SELAMAT ULANG } \\
\text { TAHUN. }\end{array}$ & $\begin{array}{l}\text { SELAMAT } \\
\text { ULANG TAHUN, } \\
\text { semoga panjang } \\
\text { umur, sehat selalu, } \\
\text { murah rezeki. }\end{array}$ & $\begin{array}{l}\text { Huruf kapital tidak digunakan } \\
\text { seluruhnya dalam sebuah kalimat }\end{array}$ \\
\hline Data 4 & $\begin{array}{l}\text { Cerita singkat } \\
\text { @ nurul maap }\end{array}$ & $\begin{array}{l}\text { Maap ku telah } \\
\text { melukis luka }\end{array}$ & $\begin{array}{l}\text { Penggunaan kata maap seharusnya } \\
\text { maaf. }\end{array}$ \\
\hline Data 5 & $\begin{array}{l}\text { Komentar @ khairul } \\
\text { fikri ya.... }\end{array}$ & Turut berduka ya.... & $\begin{array}{l}\text { Tanda titik yang dipakai pada akhir } \\
\text { kalimat pernyataan tidak } \\
\text { sesuaidengan aturan EBI }\end{array}$ \\
\hline
\end{tabular}

Tabel 2: pemakaian diksi

\begin{tabular}{|l|l|l|l|}
\hline $\begin{array}{l}\text { Nomor } \\
\text { data }\end{array}$ & $\begin{array}{l}\text { Jenis kesalahan } \\
\text { penulisan }\end{array}$ & Kalimat & Keterangan \\
\hline Data 1 & $\begin{array}{l}\text { komentar } \\
\text { @putri_insa } \\
\text { langgeng }\end{array}$ & $\begin{array}{l}\text { Semoga tetap langgeng } \\
\text { sampai kakek nenek }\end{array}$ & $\begin{array}{l}\text { Penulisan kata langgeng } \\
\text { seharusnya kekal atau abadi. }\end{array}$ \\
\hline Data 2 & $\begin{array}{l}\text { Cerita singkat } \\
\text { @gurkyy expert }\end{array}$ & $\begin{array}{l}\text { Kalau si Reza memang } \\
\text { udah expert dalam bidang } \\
\text { cari cewek cantik haha }\end{array}$ & $\begin{array}{l}\text { Penulisan kata expert } \\
\text { harusnya diganti dengan kata } \\
\text { ahli. }\end{array}$ \\
\hline Data 3 & Cerita singkat & Oke, sebentar lagi aku on & Penggunaan diksi yang tidak \\
\hline
\end{tabular}




\begin{tabular}{|l|l|l|l|}
\hline $\begin{array}{l}\text { Nomor } \\
\text { data }\end{array}$ & $\begin{array}{l}\text { Jenis kesalahan } \\
\text { penulisan }\end{array}$ & Kalimat & Keterangan \\
\hline @azura on the way & the way & $\begin{array}{l}\text { tepat struktur bahasa asing } \\
\text { dengan struktur bahasa } \\
\text { Indonesia }\end{array}$ \\
\hline Data 4 & $\begin{array}{l}\text { Postingan @ umi } \\
\text { atiku rasanya loro }\end{array}$ & Hari ini atiku rasanya loro & $\begin{array}{l}\text { Kata atiku rasanya loro, } \\
\text { seharusnya diganti dengan } \\
\text { kata rasanya hati ku sakit, ini } \\
\text { adalah bahasa daerah. }\end{array}$ \\
\hline Data 5 & $\begin{array}{l}\text { Komentar @_safitri_ } \\
\text { suwun }\end{array}$ & $\begin{array}{l}\text { Ya sudah kalau begitu, } \\
\text { suwun ya teman teman }\end{array}$ & $\begin{array}{l}\text { Kata suwun seharusnya } \\
\text { diganti dengan kata terima } \\
\text { kasih. }\end{array}$ \\
\hline
\end{tabular}

Tabel 3: kesalahan struktur tata bahasa

\begin{tabular}{|l|l|l|l|}
\hline $\begin{array}{l}\text { Nomor } \\
\text { data }\end{array}$ & $\begin{array}{l}\text { Jenis kesalahan } \\
\text { penulisan }\end{array}$ & Kalimat & Keterangan \\
\hline Data 1 & $\begin{array}{l}\text { Postingan } \\
\text { radotvalent eforia }\end{array}$ & $\begin{array}{l}\text { Gak perlu tenar yang } \\
\text { penting kita main sangar } \\
\text { jangan larut eforia kita } \\
\text { fokus juara. }\end{array}$ & $\begin{array}{l}\text { Kata eforia yang benar } \\
\text { adalah euforia yang berarti } \\
\text { perasaan gembira yang } \\
\text { berlebihan }\end{array}$ \\
\hline Data 2 & $\begin{array}{l}\text { Cerita singkat } \\
\text { @ rizka jenset }\end{array}$ & $\begin{array}{l}\text { Rumah ku mati lampu, } \\
\text { karna ada jenset rumah ku } \\
\text { hidup lampu }\end{array}$ & $\begin{array}{l}\text { Kata jenset seharusnya } \\
\text { genset yang berarti mesin } \\
\text { pembangkit listrik. }\end{array}$ \\
\hline Data 3 & $\begin{array}{l}\text { Komentar } \\
\text { @ita semua }\end{array}$ & $\begin{array}{l}\text { Kita semua harus berhati- } \\
\text { hati jaga adik kita karena } \\
\text { musim penculikan anak }\end{array}$ & $\begin{array}{l}\text { Penggunaan kata jamak yang } \\
\text { sama menjadikan pleonasme } \\
\text { sehingga gunakan salah satu } \\
\text { dalam kalimat. }\end{array}$ \\
\hline
\end{tabular}

\section{Bentuk variasi kesalahan penggunaan Bahasa Indonesia di Instagram}

\section{Variasi Bahasa Indonesia Gaul dan Bahasa Inggris}

Bahasa Inggris dalam status dan komentar di Facebook dan sosial media lainnya merupakan bentuk kreativitas penulis untuk menciptakan bahasa yang menarik. Masuknya unsur bahasa Inggris digunakan dalam bentuk kata, frase maupun kalimat. Sebagian besar pemakaiannya bahasa Inggris hanya terdiri satu atau dua kata, namun ada juga dipakai untuk satu kalimat penuh, misalnya pada kalimat i like your status (aku menyukai statusmu). Berikut ini adalah bentuk variasi bahasa Indonesia gaul dan bahasa Inggris pada sosial media yaitu status Instagram dan status Whatsapp. 
Tabel 4. Variasi Bahasa Indonesia Gaul dan Bahasa Inggris

\begin{tabular}{|c|c|c|}
\hline No & Data & Hasil prafrase \\
\hline 1. & $\begin{array}{l}\text { Postingan@azurablzr } \\
\text { Back to hme alone, efk jm tambhn } \\
\text { jlang ujian sem }\end{array}$ & $\begin{array}{l}\text { Back to home alone, efek jam tambahan } \\
\text { menjelang ujian semester }\end{array}$ \\
\hline 2 & $\begin{array}{l}\text { Wandi mooclboster } \\
\text { bat masyaallah } \\
\text { 'I ngekeh akutuh } \\
\text { 'malam minggu } 9 \\
\text { perlu ada duit. } \\
\text { yg penting stel. } \\
\text { gantemo @ nurul }\end{array}$ & $\begin{array}{l}\text { Wandi moodboster banget Masya Allah } \\
\text { aku ketawa malam minggu engga perlu ada } \\
\text { duit yang penting style ganteng. }\end{array}$ \\
\hline
\end{tabular}

Variasi Bahasa Indonesia gaul, Bahasa Inggris, dan Bahasa Daerah

Variasi bahasa indonesia gaul, bahasa Inggris, dan bahasa daerah merupakan penggabungan tiga bahasa yang menarik. Hal itu bisa terjadi karena penulis status, komentar di facebook dan instagram. Pada umum nya bertempat tinngal di surabaya dengan Bahasa Jawa sebagai bahasa ibu. Dengan demikian tidak heran apabila pada status, komentar di facebook dan instagram.

Tabel 5. Variasi Bahasa Indonesia gaul, Bahasa Inggris, dan Bahasa Daerah

\begin{tabular}{|l|l|l|}
\hline No & Data & Hasil prafrase \\
\hline 1 & $\begin{array}{l}\text { Postingan @ rayanaputri__ } \\
\text { Huj4n Yg 14m4.... marmosy! Sre! } \\
\text { Upl3v31 }\end{array}$ & $\begin{array}{l}\text { Hujan yang lama..... marai emosi! Up } \\
\text { level }\end{array}$ \\
\hline 2 & $\begin{array}{l}\text { Komentar @_maychantika_k4lYan } \\
\text { tu di enteny kok YO ra rumrongos } \\
\text { ngry tingkat tingGII }\end{array}$ & $\begin{array}{l}\text { Kalian itu dienteni kok yo ora rumongso } \\
\text { angry tingkat tinggi. }\end{array}$ \\
\hline
\end{tabular}

\section{SIMPULAN}

Hasil penelitian di atas, dapat kita lihat bahwa bahasa yang kita gunakan di Instagram dan sosial media lainnya seiring dengan berjalannya waktu dapat menurunkan kaidah-kaidah yang terdapat didalamnya. Ini karena, sosial media merupakan tempat berkumpulnya semua ragam bahasa, baik yang masih dalam bahasa Indonesia maupun yang dari luar, yang mengakibatkan pengguna tidak lagi memperhatikan bagaimana menulis bahasa Indonesia yang benar. Sebenarnya sah-sah 
saja bagi mereka (terutama remaja) yang menggunakan bahasa alay, karena hal tersebut merupakan bentuk kreatifitas yang mereka buat. Namun sebaiknya penggunaan bahasa alay dapat digunakan sesuai dengan situasi dan kondisi atau tidak digunakan pada situasi-situasi yang formal. Misalnya pada saat berbicara dengan teman. Teman disini adalah mereka yang mengetahui dan mengerti bahasa alay tersebut. Tetapi juga jangan sampai menghilangkan budaya berbahasa Indonesia kita. Karena biar bagaimanapun bahasa Indonesia tetap menjadi bahasa kebanggaan kita dan wajib untuk dijaga serta dilestarikan.

\section{REFERENSI}

Chaer, Abdul dan Leonie Agustina. Sosiolinguistik Perkenalan Awal .Jakarta: Rineka Cipta,2

Chaer, Abdul. 2007. LingusitikUmum. Jakarta: Rineka Cipta.

Nababan, P.W.J. 1993. Sosiolinguistik: Suatu Pengantar. Jakarta: Gramedia Pustaka Utama.

Moleong, Lexy J. 2004. Mahsun , MS. 2005. Metode Penelitian Kualitatif. Bandung: Rosdakarya 